\title{
Logistics Solutions in the Preparation Phase for the Appearance of Disasters
}

Erika Barojas-Payán ${ }^{*}, 1$, Diana Sánchez-Partida ${ }^{2}$, Miguel-Josué Heredia-Roldan ${ }^{3}$, Victorino Juárez-Rivera ${ }^{1}$, Jesús Medina-Cervantes ${ }^{1}$

${ }^{1}$ Faculty of Engineering, Veracruz University, Xalapa 94466, Mexico

${ }^{2}$ Department of Logistics and Supply Chain Management, Universidad Popular Autónoma del Estado de Puebla, Puebla 72410, Mexico

${ }^{3}$ Gustavo A. Madero Technological Institute, Technological National of Mexico, Mexico 07470, Mexico

\begin{tabular}{l} 
A R T I C L E I N F \\
\hline Article history: \\
Received: 14 April, 2 \\
Accepted: 03 June, 2 \\
Online: 28 July, 202 \\
\hline Keywords: \\
Warehouse location \\
Inventory levels \\
Routing Problem
\end{tabular}

\section{Introduction}

This document is an extension of an original work presented at the "2019 IEEE International Conference on Engineering Veracruz (ICEV)" [1], which derives from a global problem, such as the impact of natural phenomena of hydrometeorological type on the world. The Office of the United Nations Organization (UN) for Humanitarian Affairs (2020), mentions that from the year 2000 to date, 152 million Latin Americans and Caribbean people have been affected by 1205 disasters, including floods, hurricanes and storms, earthquakes, avalanches, droughts, fires, extreme temperatures and volcanic events [2]. It should be mentioned that natural phenomena do not affect society in the same way; the socalled hydrometeorological phenomena such as heavy rains and floods have a higher frequency compared to other types of natural phenomena and tend to affect the same region in relatively frequent periods. In the last 20 years, these were responsible for causing $90 \%$ of economic losses worldwide.

In Mexico, the effects of hydrometeorological phenomena appear depending on the distribution of the population throughout ${ }^{*}$ Corresponding Author: Erika Barojas-Payán, Ixtaczoquitlán, Ver., Mex., Email: eribarojas@gmail.com www.astesj.com

https://dx.doi.org/10.25046/aj050438 its territory. In a broad sense, northern Mexico is characterized by low levels of precipitation, frequent droughts, and recurring heat waves. In contrast, the south of the country has the highest records of recurrent precipitation and flooding, in addition to being the region most affected by the effects of hurricanes and other tropical storms. During 2016 these were responsible for causing $86 \%$ of the damage in Mexico [3, 4].

The National Civil Protection System (SINAPROC, for its acronym in Spanish), was created to respond to this and other types of natural phenomena. The said system, together with various federal and state agencies, organizations, and entities, creates the necessary instruments and mechanisms in order to carry out coordinated actions in the area of civil protection [5].

Within SINAPROC, there is the National Fund for Natural Disasters (FONDEN, for its acronym in Spanish), which is an inter-institutional mechanism that aims to execute actions, authorize and apply resources to mitigate the effects of a disturbing natural phenomenon, in regarding of the SINAPROC. For access to that fund, the Federal Government's Ministry of the Interior may issue: a) an emergency declaration, i.e., an act by which the 
Ministry recognizes that one or more territorial demarcations or municipalities are in imminence, high probability of presence of an abnormal situation generated by a disturbing agent. Therefore, immediate assistance is required to the population whose safety and integrity are at risk, or b) a disaster declaration, i.e., the act by which the Secretary recognizes the presence of a natural agent. Severe disturbance in particular municipalities, whose damage exceeds the local financial and operational capacity for their care, in order to access resources from the financial instrument for natural disaster care $[6,7,8]$.

Based on the previous information, it should be noted that the southern states and the Gulf of Mexico coasts such as Veracruz, Guerrero, Tabasco, Chiapas, and Oaxaca concentrate the expenses to support the reconstruction of damaged or destroyed infrastructure by FONDEN due to the effects of hydrometeorological events. While, in the northern region of Mexico, the states of Nuevo León and Baja California Sur were the ones that required the largest amounts [9].

Likewise, Table 1 contains a synthesis of the declarations issued during the period covered from 2000 to January 2020, by FONDEN, for the states of the southern zone and the coast of the Gulf of Mexico. It can be seen: a) the number of municipalities that the state houses; $b$ ) the number of disaster declarations; and $c$ ) the number of declarations of emergency. In that Table, it can be identified that the most significant number of declarations are issued on the state of Veracruz.

Table 1: Declarations from 2000 - 2020

\begin{tabular}{|c|c|c|c|}
\hline State & $\begin{array}{c}\# \text { of } \\
\text { municipalities }\end{array}$ & $\begin{array}{c}\text { disaster } \\
\text { declaration }\end{array}$ & emergency declaration \\
\hline Chiapas & 118 & 59 & 75 \\
\hline Guerrero & 81 & 34 & 36 \\
\hline Oaxaca & 570 & 61 & 95 \\
\hline Tabasco & 17 & 14 & 31 \\
\hline Veracruz & 212 & 114 & 205 \\
\hline
\end{tabular}

Own elaboration with information from $[9,10]$.

Based on that information, the present document evaluates the model presented in [1], whose bases fall on the problems of a) location of facilities, $b$ ) inventory levels, and $c$ ) multiple vehicle routing with capacity. All this, to generate a feasible solution that allows the establishment of a pre-positioning warehouse, with product inventory levels that allow supplying people affected by a hydrometeorological phenomenon, as well as their delivery routes. In order to provide a decision-making tool to institutions in the face of disaster.

Unlike the conference document, this research expands the geographical space, carrying out the zoning of the state of Veracruz, and the application of the model to one of them. This central area is made up of 90 municipalities, of which 66 of them were affected by some hydrometeorological phenomenon during 2016, as well as the expansion of products to be supplied, introducing the health one.

The document is made up of the following sections from this: a) Literary Review, contains studies carried out by researchers immersed in the area of emergency logistics; b) Methodology, shows step by step how the research was carried out until the results were obtained; c) Conclusions, to which the authors arrived, after an analysis of results and d) Bibliographic sources, for support and foundation of the research.

\section{Literate Review}

Relief operations often focus on response rather than preparedness due to the unpredictability of natural disasters. It leads to reactive rather than proactive systems. The effectiveness of the response may be determined by the structure of the supply chain [11]. These supplies can be said to be preparatory elements if some (or many) of them are available when needed, within strategic establishments [12]. Since the main cause and magnitude of the event of most disaster scenarios in Mexico is unknown, it is very complex to make some kind of forecast, but it is possible to prepare for it.

In recent years, many researchers from various countries have addressed the problem of the location of facilities in various fields and areas, an example of this is the health area, in which optimal location of hospitals, clinics, warehouses of medicines, and natural disaster centers that allow them to provide their services to the highest number of people in the shortest time. Decision making regarding the optimal or feasible location of a facility involves both significant investment and operating costs from the start of the project, which is why this is a crucial issue to be studied [13].

Research has been carried out over time regarding the issue of humanitarian logistics, and these documents reflect the application of different methodologies, methods, and tools in any of the stages of the disaster: (1) prevention; (2) mitigation; (3) preparation; (4) alert; (5) response; (6) rehabilitation, or (7) reconstruction [14].

These inquiries take as a basis for study one or several elements of logistics, such as the location of facilities, which have been captured in [15], where researchers examine the problem through a survey focused on four different models: 1. Deterministic; 2. Stochastic; 3. Dynamic, and 4. Robust.

In the same way in [16], they present two models, one deterministic, which considers the dependence of the damages about the distance between the disaster response facilities and the location of the affected population, and another stochastic, which extends the first concerning the intensity of the damage. A cost advantage of the second model over the first is demonstrated. Likewise, the researchers of [17], raise the impact of the mean time between disasters (MTBD) in the strategy of pre-positioning of medical supply inventory. The authors carry out a compensation model implemented on a platform based on a spreadsheet. In this area, we can mention the authors in [18], who propose a relocation of sites for the delivery of support in Mexico, through the problem of the p-median modeled in the LINGO software, thereby achieving the minimization of the current path at $25 \%$. Meanwhile, in [19], the authors develop a stochastic programming model for shelter location in disaster preparedness, introducing a Genetic Algorithm (GA) for larger instances.

In addition to the above, some authors carry out studies focused on the location of facilities, adding the capacity term, in order to supply the victims assigned to it, such as the case of [20] whose study focuses on the location of warehouses for the distribution of humanitarian aid and its capacity, through a mixed-integer linear programming model. 
Another element of logistics through which different investigations have been carried out under different optimization models, heuristics and hybrids, is the problem of vehicle routing, among which, it is worth mentioning [21], where multiple vehicle routing is presented with stochastic demand, in which researchers develop a nonlinear mathematical model with a probability constraint approach. This model is linearized with separable programming methods. While researchers in [22] develop a greedy iterative heuristic for vehicle routing with stochastic post-disaster times. Likewise, the researchers in [23] propose a model that determines the policy of resupply of products in disaster containers and generates the optimal route for vehicles to carry out the activity, maximizing the total benefits from sales revenue and costs of transport in a planning horizon. It is worth mentioning the investigation of [24], It is developed in a municipality in the state of Veracruz, Mexico, within which the heuristics of the closest neighbor $(\mathrm{NN})$ generate product delivery trajectories to localities in the emergency phase of the disaster.

Traditional approaches had analyzed production, inventory, and transport operations separately rather than considering the entire operation as a whole [25, 26]. For example, when deciding inventory levels and product shipments in a given logistics network, inventory levels were generally determined first, and then product shipments were determined. However, as industries have become global and more competitive, simultaneous analysis of complex interactions between production and distribution operations has become essential to achieve efficiency [27].

Other integrated network models include [28], which studies an integrated production and transportation planning model with multiple retailers, products, and time frames. He used a two-phase heuristic model to solve the resulting mixed-integer program. Heuristics first gets an initial solution for distribution and production decisions.

However, the literature is scarce in terms of integrative approaches that consider a comprehensive plan that covers both aspects: plant location, inventory levels, and product supply. Only recent works take into account these two dimensions of the problem $[29,30]$.

In this scale, three logistical elements are introduced, such as location, inventories, and routing, such as the case [31], in which researchers address a plan to transfer of people affected by a flood to safe areas, they formulate a linear and mixed programming model, which allows defining the location and number of shelters and distribution centers with a pre-positioned inventory of aid packages, in addition to the evacuation routes for the victims.

\section{Methodology}

The research considers two of the regions immersed in the subject state of Veracruz that is used as a case study, called the Capital Region and the High Mountains Region, which are located in the central area of the entity. This region is composed of 90 municipalities. Moreover, 66 of its municipalities have been emergency declarations by the National Fund for Natural Disasters during 2016. Figure 1, shows the methodology to be followed, begins with the collection, selection, and analysis of the information, continues with the programming of the logistics model that allows the location of a host municipality for the installation of the pre-positioned warehouse, the calculation of the levels of each product for said warehouse and the set of routes for the delivery of products, to end with the analysis of the results obtained.

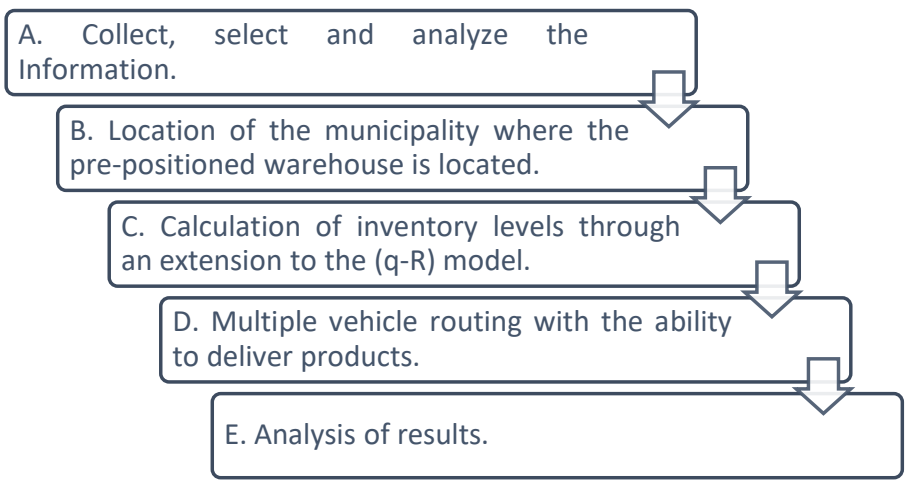

Figure 1: Applied methodology

\subsection{Collect, select, and analyze the information.}

An analysis of the information necessary to feed the model from [1] and its evaluation is carried out, which is described in the following paragraphs.

- Matrix of distances between municipalities with the emergency declaration and municipalities without the emergency declaration, using the Google Earth Pro ${ }^{\circledR}$ application, the distances are obtained that will allow the creation of the base matrix to locate a municipality without an emergency declaration in 2016 for the installation of the prepositioned warehouse and the routes to the municipalities affected by the natural phenomenon in the same year, for the delivery of products.

- Positional weight, is the value made up of the degree of satisfaction that a municipality meets according to its attributes of a) highway infrastructure, highway type; b) services, water, network, telephone, drainage, electricity, c) not being a reason for issuing an emergency declaration, that is, not having been impacted by the hydrometeorological phenomenon, and d) constructed buildings. This variable, together with the distance, will allow finding the municipality where the pre-positioning warehouse is located. The data was extracted from the pages of $[32,33,34]$.

- Demand, five types of demand: a) early childhood; b) childhood; $c$ ) adolescence; $d$ ) adulthood, and $e$ ) old age; taking as a reference to the World Health Organization, ruling out the peculiar stages such as pregnancy. The calculation of victims is based on the emergency declarations issued and the number of people by type of demand that lives in the area [35].

- Products, the items to be supplied, will be calculated in the form of kits: $a$ ) food; $b$ ) equipment (clothing, hygiene, and protection); c) health, and $d$ ) water. The first two, calculated according to the type of demand and the last two for total demand.

- $\quad$ Total Inventory cost includes a) ordering cost, b) purchasing cost, c) cost per shortage, and d) holding cost, $[1,36,37,38]$.

3.2. Location of the municipality where the pre-positioned warehouse is located

For the location of the host municipality of the pre-positioned warehouse, the p-median problem is taken as a base, adding the 
positional weight variable, with which not only minimum routes are sought, but also adequate conditions for the management of the warehouse. Below is the mathematical formulation:

$$
\begin{gathered}
\min \sum_{i=1}^{n} \sum_{j=1}^{m} w_{i} d_{i j} x_{i j} \\
\text { subject to } \\
\sum_{j=1}^{m} x_{i j}=1, \quad \forall_{i}, \\
x_{i j} \leq y_{j}, \quad \forall_{i j}, \\
\sum_{j=1}^{m} y_{j}=p \\
x_{i j}, y_{j} \in\{0,1\}
\end{gathered}
$$

Where: equation (1) objective function, seeks to minimize the sum of the distances $d_{i j}$ traveled for each location of the demand, $w_{i}$ being the variable that qualifies the attributes of each location with the possibility of hosting the facility; equation (2) confirms that each client is assigned to a single facility $n$; equation (3) confirms that each customer is supplied by a single facility; equation (4) assign $p$ facilities, and equation (5) indicates that the variables are binary [18].

\subsection{Inventory level calculation through an extension to the (q-R) model}

The following mathematical formulation shows how the calculation of inventory levels for the different types of demand is carried out, which is an extension of the (q-R) model.

$$
\begin{gathered}
\min \sum_{i=1}^{I} \sum_{j=1}^{J} \sum_{p=1}^{P}\left[\frac{C o_{i}^{p} D_{j}^{p}}{Q_{i j}^{p}}+C S_{i}\left(\frac{Q_{i j}^{p}}{2}+z_{c l s} * S_{j}^{p p}\right)+C_{i}^{p} D_{j}^{p}\right. \\
\left.+\frac{D_{j}^{p}}{Q_{i j}^{p}}\left(C f_{i}^{p}+S_{D_{j}}^{p} * E_{z_{i}}^{p}\right)\right] \\
\text { subject to } \\
R_{D_{j}}^{p}=D_{j}^{p} * L_{i}+z_{C S L} * S_{D_{j}}^{p p} \quad i=1,2, \ldots, I j=1,2, \ldots, J p=1,2, \ldots, P \\
Q_{i j}^{p}=\sqrt{2 C o_{i} \frac{\sum_{j=1}^{J} Y_{i j}^{p} D_{j}^{p}}{C s_{i}^{p}}} i=1,2, \ldots, I \quad j=1,2, \ldots, J \quad p=1,2, \ldots, P \\
E_{z_{i}}^{p}=z\left[F_{s}^{p}(z)-1\right]+f_{s}^{p}(z) \quad i=1,2, \ldots, I \quad p=1,2, \ldots P \\
F R_{i}^{p}=1-\frac{s_{j}^{\prime p} E_{z_{i}}^{p}}{Q_{i j}^{p}} \quad i=1,2, \ldots, I \quad p=1,2, \ldots, P \\
Q_{i j}^{p} \in Z^{+}
\end{gathered}
$$

The equation (6), seeks to minimize costs and is made up of: a) ordering cost, $\frac{C o_{i}^{p} D_{j}^{p}}{Q_{i j}^{p}} ;$ b) holding $\operatorname{cost} C s_{i}^{p}\left(\frac{Q_{i_{j}}^{p}}{2}+z_{c l s} * S^{\prime p}{ }_{D_{j}}\right)$; c) purchasing cost, $C_{i}^{p} D_{j}^{p}$, and d) Stockout cost $\frac{D_{j}^{p}}{p_{i j}^{p}}\left(C f_{i}^{p}+S_{D_{j}}^{p} *\right.$ $\left.E_{z_{i}}^{p}\right)$; the equation (7), performs the calculation of the adjusted standard deviation for each demand $\left(S_{D_{j}}^{\prime p}\right)$. It is mentioned that the demand has a normal distribution of its data; the equation (8), performs the calculation to obtain the point to which the inventory of products ( $p$ ) of each of the demands of the affected municipalities $\left(D_{j}\right)$ must reach, to issue a purchase order for these; equation (9), determines the number of products $(p)$ to order for the pre-positioning warehouse (i) that will allow supplying the different demands of the affected municipalities $(j)$; equation (10), evaluates the probability of shortages to victims of products $(p)$; equation (11) measures the level of product delivery service $(p)$ of the pre-positioned warehouse located in the municipality (i) for municipalities $(j)$, and finally, equation (12), indicates that $\left(Q_{i j}^{p}\right)$ is the integer variable.

\subsection{Multiple vehicle routing with the ability to deliver products}

Through the problem of vehicle routing with capacity, the necessary routes are obtained that will allow supplying products to people affected by the natural phenomenon of hydrometeorological type, and the mathematical formulation starts from:

The two-index vehicle flow formulation type linear programming model uses $O\left(n^{2}\right)$ binary variables of $x_{i j}$ to indicate with a value of 1 if the arc $(i, j) \in A$ belongs to the optimal solution and takes a value of 0 otherwise $[39,40]$.

$$
\begin{aligned}
& \min \sum_{i \in V} \sum_{j \in V} c_{i j} x_{i j} \\
& \text { subject to } \\
& \sum_{i \in V} x_{i j}=1 \quad \forall j \in V \backslash\{0\} \\
& \sum_{j \in V} x_{i j}=1 \quad \forall i \in V \backslash\{0\} \\
& \sum_{i \in V} x_{i 0}=K, \\
& \sum_{j \in V} x_{0 j}=K \text {, } \\
& \sum_{i \notin S} \sum_{j \in S} x_{i j} \geq r(S) \quad \forall S \subset V \backslash\{0\}, S \varnothing \\
& x_{i j} \in\{0,1\} \quad \forall i, j \in V
\end{aligned}
$$

Where: $\mathcal{V}=\left\{v_{0}, v_{1}, \ldots v_{n}\right\}$ is the set of vertices of the graph, where $v_{0}$ corresponds to the warehouse; $C$ is the distance or cost matrix $c_{i j}$ between customers $v_{i}$ and $v_{j} ; K$ is the number of capacity $C$ vehicles needed to load all the demand; $S$ is a set of vertices of the graph where $S \subset V \backslash\{0\}$, and $r(S)$ is the minimum number of vehicles necessary to serve all customers in $S$.

In this way, equations (14-15), ensure that a single arch enters and a single arch leaves each vertex, clients are visited only once; while equations (16-17) ensure that the number of vehicles leaving the warehouse (vertex) return to it; while equation (18) satisfies connectivity and non-violation of vehicle capacity.

\subsection{Analysis of the results}

- Impacted and non-impacted municipalities.

Table 2 shows the zoning of the state of Veracruz that is established to carry out this document, as can be seen, part of its regionalization. Table 2 shows the number of municipalities that each area houses and the number of municipalities impacted by a natural phenomenon of hydrometeorological type during 2016, the percentage of emergency declarations issued by FONDEN of a total is shown in the last column of 147 [41]. The central zone is taken as a reference for evaluating the model, derived from the fact that it is the one with the most significant number of municipalities and more than $50 \%$ of declarations issued.

- Vehicle capacity. 
The same vehicular capacity is set as in [1], 4913 kits.

Table 2: Zoning of the state of Veracruz

\begin{tabular}{|c|c|c|c|c|}
\hline Zone & \multicolumn{1}{|c|}{ Regions } & $\begin{array}{c}\# \\
\text { municipalities }\end{array}$ & $\begin{array}{c}\text { Impacted } \\
\text { municipalities }\end{array}$ & $\begin{array}{c}\% \\
\text { declarations }\end{array}$ \\
\hline North & $\begin{array}{l}\text { Huasteca Alta, } \\
\text { Huasteca Baja, } \\
\text { Nautla, } \\
\text { Totonaca }\end{array}$ & 59 & 26 & $21.77 \%$ \\
\hline Center & $\begin{array}{l}\text { Capital, Altas } \\
\text { Montañas }\end{array}$ & 90 & 66 & $51.70 \%$ \\
\hline South & $\begin{array}{l}\text { Los Tuxtlas, } \\
\text { Olmeca, } \\
\text { Papaloapan, } \\
\text { Sotavento } \\
\text { Total }\end{array}$ & 63 & 31 & $26.53 \%$ \\
\hline & \begin{tabular}{l} 
Total \\
\hline
\end{tabular} & 123 & $100 \%$ \\
\hline
\end{tabular}

- Location of the host municipality of the pre-positioned warehouse.

For the location of the host municipality, four different scenarios are proposed for the location of host municipalities of the pre-positioned warehouse. The first scenario designates the municipality of Fortín de las Flores as the headquarters of the aforementioned warehouse, which is obtained from the 24 municipalities without issuing an emergency declaration and the 66 municipalities impacted in 2016. The second scenario, part of rule out the municipality obtained in the first scenario (Fortín de las Flores) to give rise to the municipality of Emiliano Zapata as headquarters, the discard is from the assumption that the municipality first obtained, is impacted at a particular moment by a natural phenomenon of the type hydrometeorological. The third scenario is carried out in the event that the two previous municipalities cannot house the pre-positioned warehouse, Paso del Macho is obtained as the host municipality. A fourth scenario is captured, suppressing the variable of positional weight, that is, without taking into account the attributes of each municipality except that of affectation by a natural hydrometeorological phenomenon, thus the municipality of Atoyac, Miguel Alemán becomes the headquarters of the warehouse, which is located at a distance of $29.6 \mathrm{~km}$ from the first seat municipality, that is, Fortín de las Flores.

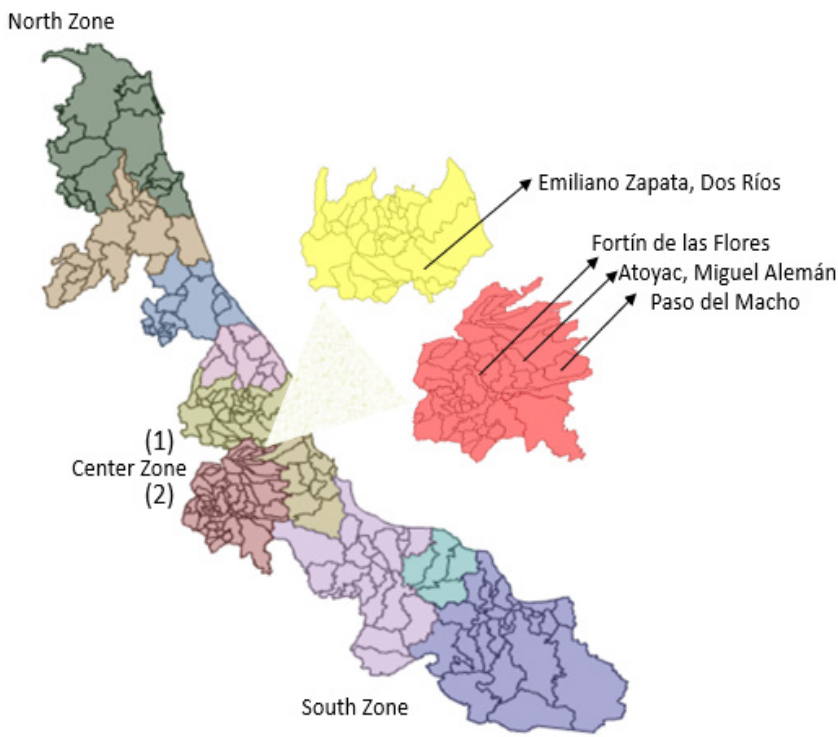

Figure 2: Municipalities headquarters of the pre-positioned warehouse [42]
While Figure 2 shows the regionalization of the state in the study, it should be remembered that in previous paragraphs, the state was zoned, based on this regionalization. The regions that make up the central area subject to study are the Capital region (1) and the High Mountains Region (2).

The location of each of the selected municipalities is shown in Figure 2: 1. Emiliano Zapata; 2. Fortín de las Flores; 3. Atoyac, Miguel Alemán, and 4. Paso del Macho.

\section{- Inventory levels.}

The levels of inventory of food, equipment, water, and medicines grouped in kits are shown in Table 3. It shows the economic order quantities, the reorder point, the safety inventory, and the number of people not supplied.

Table 3: Inventory levels

\begin{tabular}{|l|l|c|c|c|c|}
\hline $\begin{array}{c}\text { TYPE OF } \\
\text { DEMAND }\end{array}$ & Kits & $\begin{array}{c}\text { Economic } \\
\text { order } \\
\text { quantity } \\
\left(Q_{i j}^{p}\right)\end{array}$ & $\begin{array}{c}\text { Re- } \\
\text { order } \\
\text { point } \\
\left(R_{j}^{p}\right)\end{array}$ & $\begin{array}{c}\text { Safety } \\
\text { stock }\end{array}$ & $\begin{array}{c}\text { None- } \\
\text { supplied }\end{array}$ \\
\hline $\begin{array}{c}\text { Demand_1 } \\
D_{j}^{p^{-}}\end{array}$ & Food & 15732 & 6545 & 653 & 1 \\
\hline $\begin{array}{c}\text { (Early } \\
\text { childhood) }\end{array}$ & Equipment & 15521 & 6545 & 653 & 1 \\
\hline $\begin{array}{c}\text { Demand_2 } \\
D_{j}^{p^{-}} \\
\text {(childhood) }\end{array}$ & Food & 32793 & 13999 & 1443 & 3 \\
\hline $\begin{array}{c}\text { Demand_3 } \\
D_{j}^{p^{-}}\end{array}$ & Fquipment & 32793 & 13999 & 1443 & 3 \\
\hline (adolescence) & Equipment & 48396 & 20353 & 1781 & 3 \\
\hline $\begin{array}{c}\text { Demand_4 } \\
D_{j}^{p^{-}}\end{array}$ & Food & 37000 & 15460 & 1275 & 2 \\
\hline $\begin{array}{c}\text { (adulthood) } \\
\text { Demand_5 }\end{array}$ & Equipment & 37000 & 15460 & 1275 & 2 \\
\hline $\begin{array}{c}D_{j}^{p^{-}} \\
\text {(old age) }\end{array}$ & Food & 9078 & 3755 & 327 & 1 \\
\hline $\begin{array}{c}\text { Demand_6 } \\
D_{j}^{p^{-}}\end{array}$ & Water & 227931 & 60014 & 5379 & 8 \\
\hline \begin{tabular}{c} 
(General) \\
\hline $\begin{array}{c}\text { Demand_6 } \\
D_{j}^{p^{-}}\end{array}$ \\
(General)
\end{tabular} & Medicine & 60014 & 28324 & 5379 & 8 \\
\hline Inventory & Cost & 9050 & 3755 & 327 & 1 \\
\hline
\end{tabular}

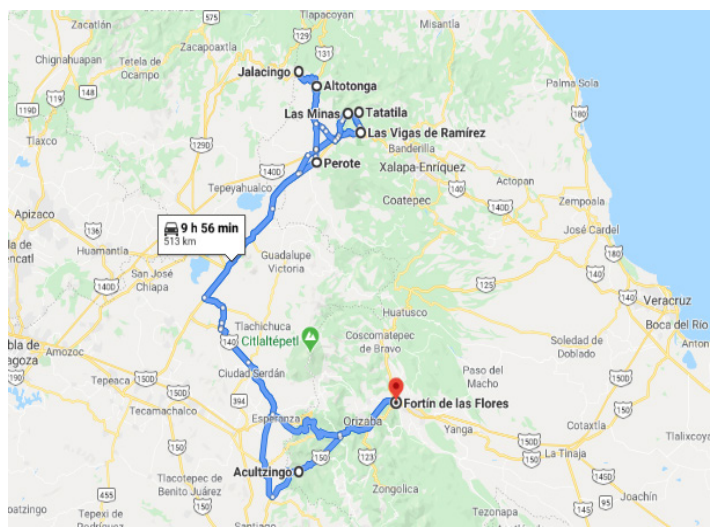




\section{- Delivery routes}

Table 4 shows 4 of the 12 delivery routes obtained with a prepositioned warehouse within the municipality of Fortín de la Flores. The overall results in the said municipality showed a total of 1,964.68 km traveled for delivery, an arithmetic mean of 163.72 $\mathrm{km}$ traveled per route, and arithmetic means of supplying victims of 6,291.45. The delivery of products can be carried out in a minimum time, under the assumption of not affecting the road infrastructure.

Figures 3, 4, 5 y 6, They show the delivery routes in Table 4, in order to be able to observe the routes to travel. For this, the application of Google Maps ${ }^{\circledR}$.

Table 4: Delivery routes

\begin{tabular}{|c|c|c|c|c|c|c|c|c|c|}
\hline \# & \multicolumn{9}{|c|}{ ROUTE } \\
\hline 1 & 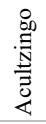 & 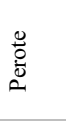 & 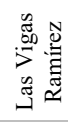 & 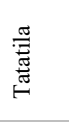 & 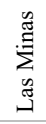 & $\stackrel{\frac{\pi}{5}}{\frac{\pi}{5}}$ & 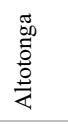 & 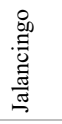 & \\
\hline 5 & 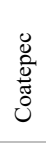 & 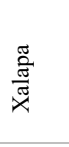 & 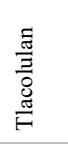 & 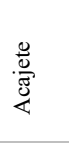 & 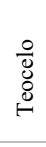 & $\stackrel{\ddot{x}}{\ddot{x}}$ & 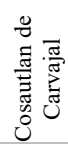 & 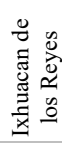 & 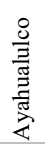 \\
\hline 7 & 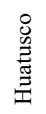 & $\begin{array}{l}\text { 节 } \\
\text { N }\end{array}$ & 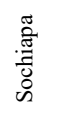 & 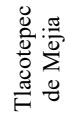 & 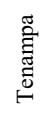 & 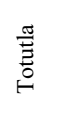 & 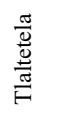 & & \\
\hline 12 & 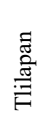 & 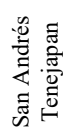 & 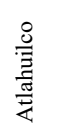 & 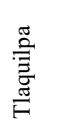 & 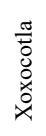 & 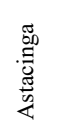 & 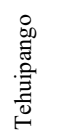 & & \\
\hline
\end{tabular}

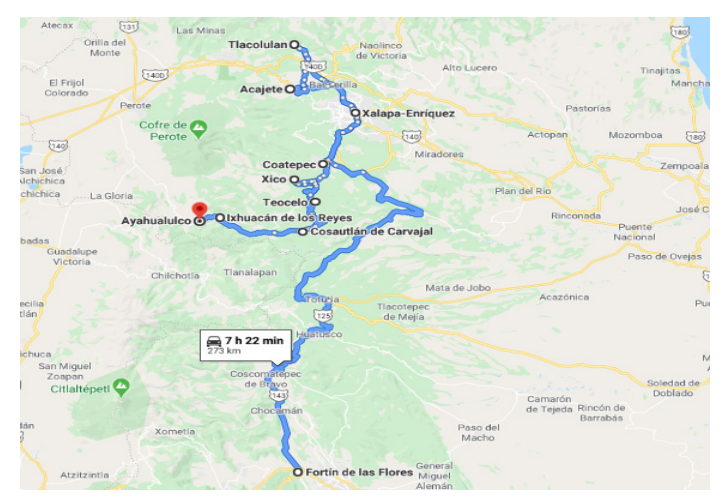

Figure 4: Route 5, $385 \mathrm{~km}$ traveled, nine municipalities supplied, extracted Google Maps ${ }^{\circledR}$

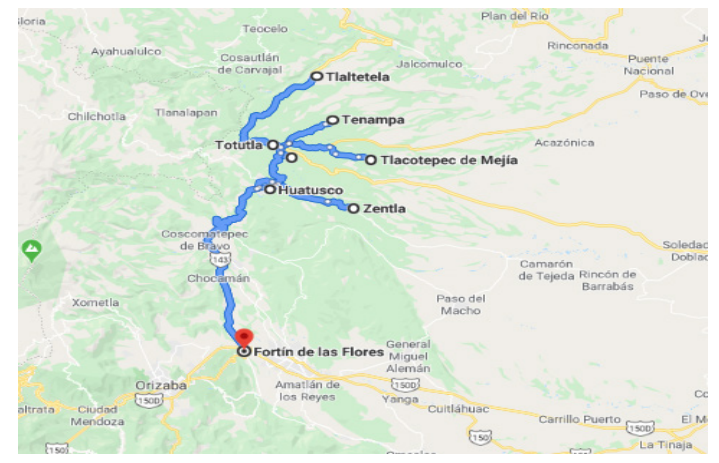

Figure 5: Route 7, 237 traveled, seven municipalities supplied, extracted from Google Maps ${ }^{\circledR}$

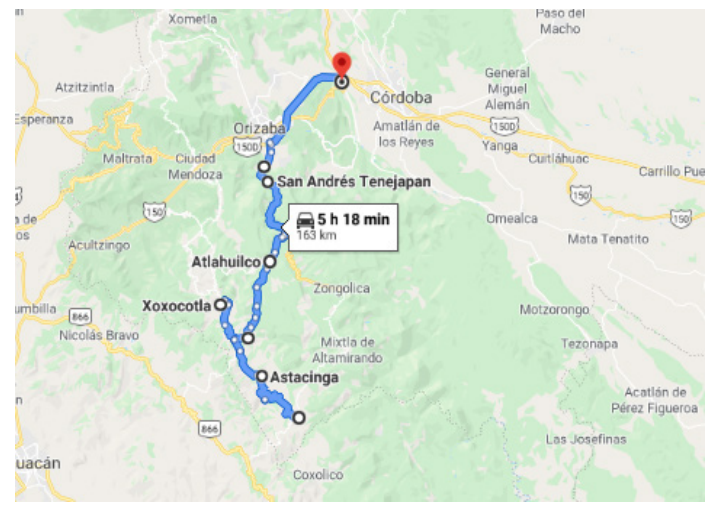

Figure 6: Route 7, $163 \mathrm{~km}$ traveled, seven municipalities supplied, extracted from Google Maps ${ }^{\circledR}$

\section{Conclusions}

Natural disasters have caused not only economic but also human losses. Mexico is not far from the effects of these events, much of its territory is exposed to the impact of natural phenomena of a hydrometeorological and geological nature, specifically the state of Veracruz, which has been considerably affected by hydrometeorological phenomena. This situation makes it imperative to locate facilities that can supply the needs, as mentioned above, to the victims in the shortest time.

The present document carries out the extension of a conference paper, evaluating the presented logistics model that has as its basis: a) the classic problem of the p-median for the location of a prepositioning warehouse; $b$ ) an extension of the (q-R) model for calculating inventories of different products, according to different types of demand, and c) the problem of multiple vehicle routing with the capacity to establish delivery routes from warehouses to the affected municipalities. The evaluation is carried out in the same federal entity, with a more significant number of instances, in total 90, which are in the central area of the state, the results show that the location of the warehouse is assigned to the municipality of Fortín de las Flores, the delivery routes to the affected municipalities are presented, obtaining a total of 12 with a total of $1964 \mathrm{~km}$ traveled and an average travel distance of $163.72 \mathrm{~km}$.

Similarly, the discarding of the municipality obtained is carried out, under the assumption that it has been affected by the natural event, obtaining another feasible location for the pre-positioned warehouse, this being the municipality of Emiliano Zapata, under the same. Of course, the latter municipality is discarded, obtaining Paso del Macho as the headquarters municipality of the warehouse. A fourth run of the program is carried out, in which the variable of positional weight and the previous municipalities are ruled out for having been affected, obtaining Atoya, Miguel Aleman, as the host municipality. In the same way, the increase in the number of products to be supplied was carried out. Therefore, the inventory levels obtained present a total cost of 640,501,050 Mexican pesos for the five demands: a) early childhood; b) childhood; c) adolescence; $d$ ) adulthood, and $e$ ) old age; with four product kits: 1. Food; 2. Equipment; 3. Health, and 4. Water.

It was carried out using the (q, R) model because the kits are supplied from 1, 2 or up to 3 times in specific time, according to the duration of the support bulletin's opening or, in accordance to 
the need of the people. We did not consider the newsboy model because it considers a single purchase. Even so, it is suggested to look for some other model that can answer this problem.

People's lives are priceless, natural phenomena are not controllable, but actions can be carried out to reduce the damage that they may cause to people immersed in impacted areas at a particular time, and maintain a quality of life for them. Until his return to his healthy life. The state of Veracruz, year after year is hit by different phenomena, but derived from its location, those of the hydrometeorological type occurs with a specific frequency, even more so in the period covered between the months of JuneNovember, which is why the research carried out, looks for feasible locations that allow the location of a pre-positioned warehouse in municipalities that meet conditions for its efficient management, and that this warehouse, in turn, contains food products, clothing, health, and clean water to ingest, at adequate inventory levels, with the aim of a resupply until the return to normality, with a delivery routing with minimum distances, so that attention is fulfilled in the shortest possible time in terms of food and health, the latter derived that diseases such as typhoid, tetanus, and lung can occur to name a few. In the literature, especially in studies carried out in this state, minimal research was visualized in the field of humanitarian logistics.

As future work, a extend model is proposed that can to locate multiple locations with their delivery routes and travel distance constraints.

\section{References}

[1] E. Barojas-Payán, D. Sánchez-Partida, V. Juárez-Rivera, R. Villafuerte-Díaz, J. Medina-Cervantes, "Plant location, inventory levels and supply of products to areas affected by a natural phenomenon" in 2019 IEEE International Conference on Engineering Veracruz (ICEV), Boca del Rio, Ver., Mex., 2019. https://doi.org/10.1109 / ICEV.2019.8920691

[2] United Nations. UN News. 2010 [Online]. Available at https://news.un.org/es/story/2020/01/1467501 Last accessed February 1, 2020.

[3] J.M. Rodríguez, C.M. Welsh, M.L. Romo, A.C. Travieso, Riesgo de desastres en México: eventos hidrometeorológicos y climáticos. Instituto Mexicano de Tecnología del Agua, 2018.

[4] Cred-Usaid, Cred crunch, Brussels, Centre for Research on the Epidemiology of Disasters. United States Agency International Development. 2016. https://www.emdat.be/publications?page $=1$

[5] Secretaria de Gobernación, Manual de organización y operación del sistema nacional de protección civil, 2018.

[6] Secretaria de Hacienda y Crédito Público, Acuerdo por el que se emiten las reglas generales del fondo de desastres naturales, Capítulo I, Disposiciones generales, Articulo $1^{\circ}, 2010$.

[7] Cámara de Diputados del H. Congreso de la Unión, Ley General de Protección Civil, Nueva Ley publicada en el Diario Oficial de la Federación el 6 de junio de 2012, 12(59), 1-6, 2018.

[8] Cámara de Diputados del H. Congreso de la Unión, Ley General de Protección Civil, Nueva Ley publicada en el Diario Oficial de la Federación el 6 de junio de 2012, Capítulo XII, 2018.

[9] Secretaría de Gobernación - Centro Nacional de Prevención de Desastres, Impacto socioeconómico de los principales desastres ocurridos en la República Mexicana en 2016, Dirección de Análisis y Gestión de Riesgos Subdirección de Estudios Económicos y Sociales México, 2018.

[10] Instituto Nacional de Estadística y Geografia. Veracruz Ignacio de la Llave. 2019. https://www.inegi.org.mx/app/areasgeograficas/?ag=30

[11] S. Saeyeon, S. Pettit, I. Harris, A. Beresford, "The pre-positioning of warehouses at regional and local levels for humanitarian relief organization" International Journal of Production Economics, 170(1) Part B, 616-628, 2015.

[12] C.G. Rawls, M.A. Turnquist, "Pre-positioning of emergency supplies for disaster response" Transportation Research Part B, 44(4), 521-534, 2009.

[13] M. S. Daskin, Network and Discrete Location: Models, Algorithms, and Applications, John Wiley and Sons, Inc., 2013.
[14] Veracruz, Gobierno del Estado. Ciclo de los desastres. 2020. http://www.veracruz.gob.mx/proteccioncivil/ciclo-de-los-desastres/

[15] C. Boonmee, M. Arimura, T. Asada, "Facility location optimization model for emergency humanitarian logistics" International Journal of disaster risk $\begin{array}{lll}\text { Reduction, } & 24(2017), & 485-498,\end{array}$ https://doi.org/10.1016/j.ijdrr.2017.01.017

[16] A. Vermaa, G, Gaukler, "Pre-positioning disaster response facilities at safe locations: An evaluation of deterministic and stochastic modeling approaches" Computers \& Operations Research, 62(2015), 197-209, 2015. https://doi.org/10.1016/j.cor.2014.10.006

[17] T. Saputra, O. Pots, K.D. de Smidt-Destombes, "The impact of mean time between disasters on inventory pre-positioning strategy" Disaster Prevention and Management, 24(1), 115-131, 2015. https://doi.org/10.1108/DPM-112013-0197.

[18] I. Landa-Cruz, D. Sánchez-Partida, E. Barojas-Payán, J.L. Martínez-Flores, "Optimization model for relocation of distribution sites of economic support in areas of high marginalization" DYNA Management, 4(1), [15], 2016 http://dx.doi.org/10.6036/MN8104

[19] M. Mostajabdaveh, W. Gutjahr, F. Salman, "Inequity-averse shelter location for disaster preparedness." IISE Transactions, 51(8), 809-829, 2019. https://doi.org/10.1080/24725854.2018.1496372

[20] C. Cornejo-Sánchez, J. Vargas-Florez, L. Aragón-Casas, V. Serpa-Oshiro, "Innovation in engineering, technology and education for competitiveness and prosperity" in Eleventh LACCEI Latin American and Caribbean Conference for Engineering and Technology (LACCEI'2013), Cancún, Q. Roo, Mex, 2013.

[21] A. USLU, C. ÇETINKAYA, SK. İSSEYEN, "Vehicle routing problem in post-disaster humanitarian relief logistics: a case study in Ankara" Sigma J Eng \& Nat Sci. 35(3), 481-499, 2017.

[22] M.E. Bruni, S. Khodaparasti, "A fast heuristic for routing in post-disaster humanitarian relief logistics" Transportation Research Procedia, 30, 304-313, 2018. https://doi.org/10.1016/j.trpro.2018.09.033

[23] M.A. Gökçe, E. Ercan, "Multi-period vehicle routing \& replenishment problem of neighbourhood disaster stations for pre-disaster humanitarian relief logistics" IFAC-PapersOnLine, 52(13), 2614-2619, 2019. https://doi.org/10.1016/j.ifacol.2019.11.601

[24] E. Barojas-Payán, D. Sánchez-Partida, D.E. Riaño, J.L. Martínez-Flores, W. Velázquez, S.O. Caballero, "Heuristic of the nearest neighbor in the delivery of supports within the state of Veracruz" International Journal of Combinatorial Optimization Problems and Informatics, 10(2), 26-38, 2018.

[25] L. Bertazzi, M. Speranza, "Models and algorithms for the minimization of inventory and transportation costs: a survey" New Trends in Distribution Logistics, 480, 137-157, 1999.

[26] C.H. Glock, "The joint economic lot size problem: A review" International Journal of Production Economics, 135(2), 671-686, 2012.

[27] A. Sarmiento, R. Nagi, "A review of integrated analysis of productiondistribution systems" IIE Transactions, 31(11), 1061-1074, 1999

[28] Y.B. Park, "An integrated approach for production and distribution planning in supply chain management" International Journal of Production Research, 43(6), 1205-1224, 2005.

[29] G. Ghiani, A. Manni, E. Manni, M. Toraldo, "The impact of an efficient collection sites location on the zoning phase in municipal solid waste management" Waste Management, 34, 1949-1956, 2014.

[30] V.C. Hemmelmayr, K.F. Doerner, R.F. Hartl, D. VIGO, "Models and algorithms for the integrated planning of bin allocation and vehicle routing in solid waste management" Transportation Science, 48, 103-120, 2014.

[31] J. Gaytán-Iniestra, P.E. Arroyo-López, R. Enríquez-Colón, "A bi-criteria model to locate shelters as part of an evacuation plan in the case of floods" Revista Ingeniería Industrial, 2, 35-56, 2012.

[32] Instituto Nacional para el Federalismo y Desarrollo Municipal, Secretaria de Gobernación. Sistema Nacional de Información Municipal: Municipios en cifras. 2017. http://www.snim.rami.gob.mx/

[33] Secretaría de Comunicaciones y Transportes. Traza tu ruta. 2017 http://app.sct.gob.mx/sibuac_internet/ControllerUI?action=cmdEscogeRuta

[34] Secretaria de Desarrollo Social. Programa de abasto rural. 2017. http://catalogo.datos.gob.mx/dataset/programa-de-abasto-rural-tiendas-2015

[35] Organización Mundial de la Salud. Biblioteca electrónica de documentación científica sobre medidas nutricionales (eLENA), "Ciclo de vida". 2017. https://www.who.int/elena/life_course/es/

[36] Procuraduría Federal del consumidor. Quién es quién en los precios. 2018 https://www.profeco.gob.mx/precios/canasta/home.aspx?th=1

[37] Servicio de Administración Tributaria. Salarios Mínimos. 2017 www.sat.gob.mx/informacion fiscal/tabla indicadores/Paginas/salarios min imos.aspx

[38] Secretaria del trabajo y previsión social. Salarios Mínimos. 2017. www.gob.mx/cms/uploads/attachment/file/175865/Tabla_de_salarios_mini mos_vigentes_a_partir_de_01_enero_2017.pdf 
[39] P. Toth, D. Vigo, An Overview of Vehicle Routing Problems, Monographs on Discrete Mathematic and Applications, SIAM, 2000.

[40] J.P. Orrego, D. Ospina, E.M. Toro, "Solución al problema de ruteo de vehículos con capacidad limitada (CVRP) usando una técnica metaheurística"

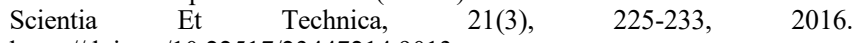
https://doi.org/10.22517/23447214.9013

[41] Sistema Nacional de Protección Civil, México DDGR (FONDEN). Insumos autorizados por declaratoria de emergencia. 2016. https://www.proteccioncivil.gob.mx/es/ProteccionCivil

[42] National Institute for Federalism and Municipal Development, SEGOB, Secretary of the Interior. National Municipal Information System: Municipalities in numbers. 2010. http://www.snim.rami.gob.mx/ 